\title{
Tension wood occurrence in three cultivars of Populus $\times$ euramericana. Part I: Inter-clonal and intra-tree variability of tension wood
}

\author{
Miguel Angel Badia, Thiéry Constant, Frédéric Mothe, Gérard NePVeU \\ LERFOB, UMR INRA-ENGREF, Wood Quality Research Team, Research Centre of Nancy, 54280 Champenoux, France
}

(Received 25 September 2004; accepted 31 May 2005)

\begin{abstract}
The main wood quality problem affecting poplar trees is tension wood occurrence associated to end-splits after felling, distortions of products, woolly wood, etc. The objective of this study was to estimate the occurrence of tension wood by using the external shape of the stem and the 3D distribution of annual growth rings. This paper is the first of two papers and presents the inter-clonal and intra-tree tension wood variability. A clear clonal-effect was observed on tension wood area percentage (I-MC $>\mathrm{I} 214>$ Luisa Avanzo). The clone with the best tree morphology (I-MC) showed the highest percentage of tension wood (15.3\%). Concerning the intra-tree variability, tension wood extent increased significantly at the tree base $(<30-50 \mathrm{~cm})$. In the radial direction of the stem, the percentage of tension wood showed an U-shape distribution. The first peak, close to the pith, corresponds to the "establishment growth period" during the open growth and the second peak, close to the bark corresponds to the "competition growth period".
\end{abstract}

tension wood / poplar / variability / cultivar / secondary growth

\begin{abstract}
Résumé - Présence de bois de tension dans trois variétés de Populus $\times$ euramericana. Partie I : Variabilité inter-clonale et intra-arbre du bois de tension. Le principal problème de qualité affectant les peupliers est la présence de bois de tension associée aux fentes à l'abattage, aux déformations des sciages, ou au bois pelucheux... L'objectif principal de ce travail est d'estimer la distribution du bois de tension à partir de la forme détaillée de l'arbre et de son empilement de cernes en 3D. Cet article est le premier d'une série de deux, où nous présentons la variabilité inter-clonale et intra-arbre du bois de tension. L'analyse de la variabilité du pourcentage surfacique de bois de tension met en évidence un fort effet clone (I-MC>I214>Luisa Avanzo) et montre aussi que le clone avec la meilleure conformation morphologique (I-MC) présente la proportion de bois de tension plus élevée $(15.3 \%)$. En ce qui concerne la variabilité intra-arbre, la proportion de bois de tension présente une augmentation significative à la base de l'arbre $(<30-50 \mathrm{~cm})$. Dans la direction radiale, la distribution du bois de tension présente une structure bi-modale en forme de « $\mathrm{U} »$. Le premier mode du côté de la moelle correspondrait à une phase de croissance libre, dite phase « d'établissement » et le second du côté de l'écorce à une phase de recherche de la lumière dite « phase de compétition ».
\end{abstract}

bois de tension / peuplier / variabilité / cultivar / croissance secondaire

\section{INTRODUCTION}

The choice of cultivars in a plantation management depends mainly on the environmental conditions, but also on their resistance to pathogens, growth rate, tree form and of course wood quality. One of the most important wood properties for the traditional use of poplar wood is the low percentage of tension wood. However, due to the complexity of tension wood measurements, this defect is not always considered in the clonal selection process. Different methods of macroscopic detection are reported in the literature: staining $[11,18,20]$, longitudinal and tangential shrinkage [12, 35], naked eye [3, 23, 28, 29], etc. However, all these techniques allowed the authors to observe a strong inter-clonal effect on tension wood variability. Sacré and Leclercq showed that tension wood proportion varies from 7.1 to $40 \%$ according to the clone $[24,31]$.
The complexity of techniques for tension wood identification have often led the authors to restrict them to only one position within the stem in order to compare several clones without considering the intra-tree variability. Researchers interested in the internal distribution of tension wood through the whole tree, and who consider the active function of reaction wood in the straight part of the tree $[4,36]$, have tried to connect the longitudinal and radial distribution of reaction wood with the tree form (lean, curves, eccentricity, etc.) $[1,7,9,13,34,37]$ and the architectural structure (effect of lateral branch development, etc.) $[10,15,25]$. In both types of studies, the main difficulty encountered in the analysis of mature trees was that the past of the trees was unknown: only the current form can be observed, but the history responsible for the final form is not accessible. The internal distribution of reaction wood can vary considerably according to this history. However, beyond the

* Corresponding auteur: constant@ nancy.inra.fr 
Table I. Main dendrometric characteristics of the trees sampled with respect to shape indices $(\mathrm{Ht}=$ total height, $\mathrm{DBH}=\mathrm{diameter}$ at breast height).

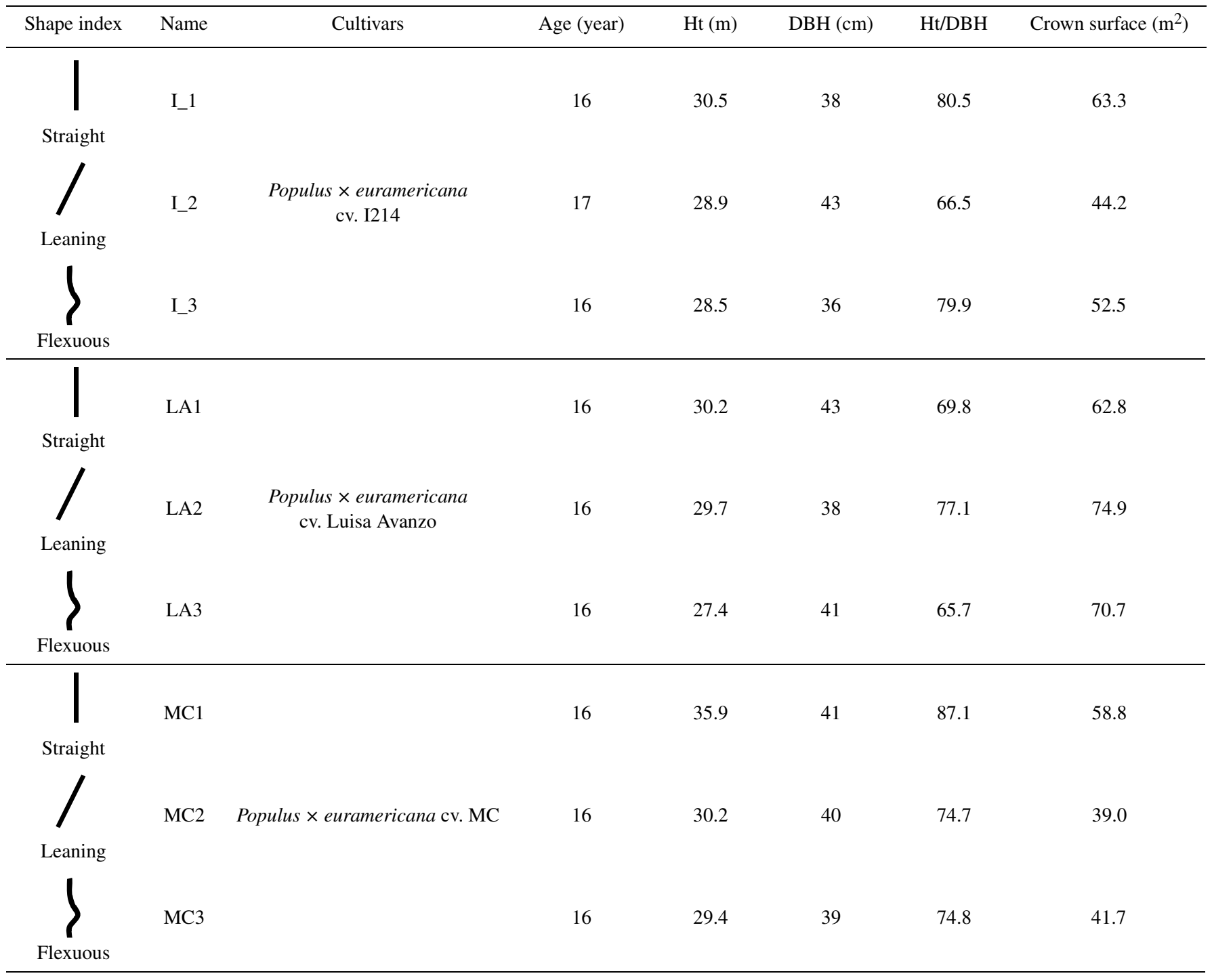

behaviour of each specimen in response to its individual environment certain constraints will be found in all specimens leading to the same response. Thus we can observe a structured pattern in the reaction wood distribution in response to controlled environmental factors such as silviculture.

In this study, we observed the tension wood variability between three of the most planted cultivars in Valley of Cinca (Spain): I214, Luisa Avanzo and I-MC, as well as the intra-tree variability. We present here the distribution of tension wood in nine stems of poplar rapidly grown under plantation management.

\section{MATERIALS AND METHODS}

Nine poplar trees were sampled in Valle del Cinca (Spain). A preliminary inventory was carried out to define the most representative typology of tree shape. A rather good homogeneity of the growth conditions (wind direction, soil, exposure, watering by flooding) was ensured by selecting the plots close to each other, and by selecting the individuals of the same cultivar in the same plantation. The plantation density was 277 stems per hectare (6 m spacing). The dendrometrical characteristics of these nine trees are illustrated in Table I.

The tree shape of the nine trees was digitised using an experimental method developed during a Ph.D. work [2]. In order to connect the occurrence of tension wood (TW) to the standing trunk shape it was necessary to find a method to calculate the tree shape, the log shape, the discs and the ring properties in the same system of coordinate. In this case, a chain of devices combining laser distancers and image analysis systems was used [14]. The result was a precise location of the characteristics measured on each disc in the standing tree. Using this information, the local lean per disc or per growth ring could be calculated as the angle between the vertical axis and a line joining the centre of gravity of the disc below and above the disc studied [14]. Then the mean local lean per tree, was calculated as the average of the different local lean per disc analysed in the stem. Figure 1 shows the three levels of shape analysis: (A) shape of the standing tree, (B) location of each disc and wood properties inside the tree, (C) disc level with growth rings and TW (dark grey). 


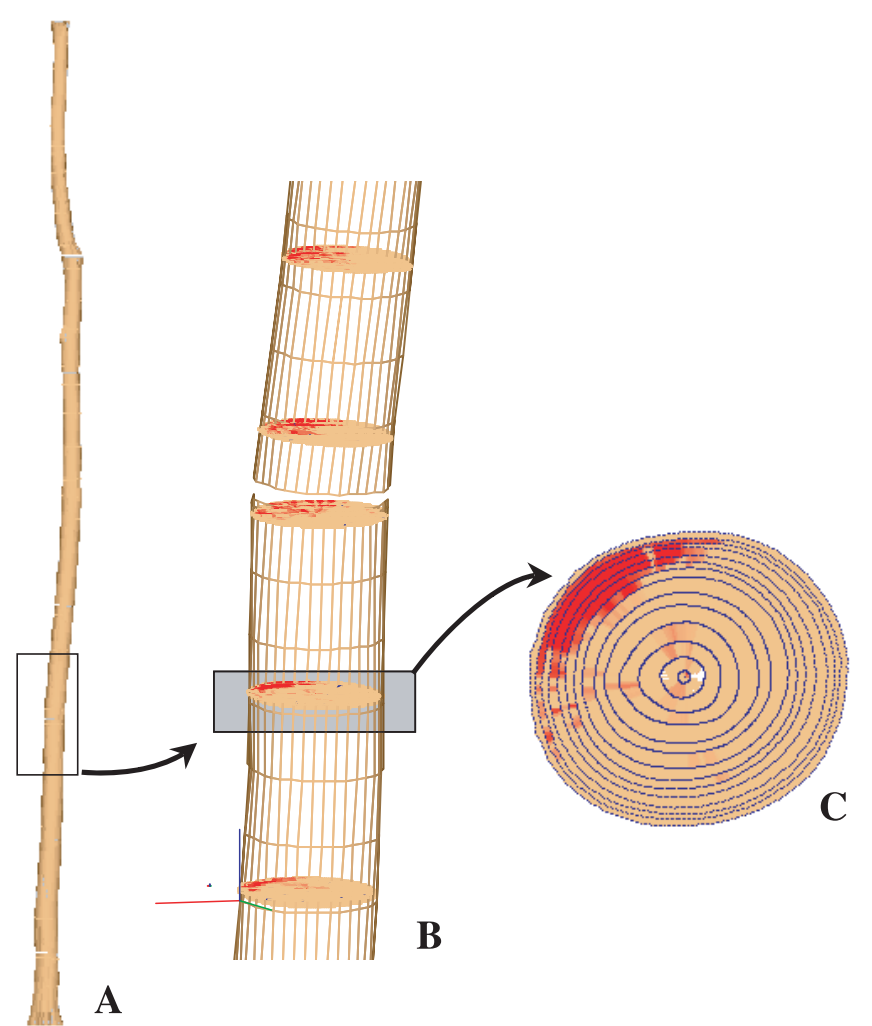

Figure 1. Illustration of the three levels of shape analysis for poplar tree I_3: (A) skeleton of the standing tree, (B) reconstruction of the tree shape and of the sampled discs, (C) disc measurements: growth rings and tension wood.

The macroscopic identification of TW was done by the naked eye $[3,23,28,29]$. It was performed by using the highest reflection of some areas under a low-angle natural light (Fig. 2). These areas with a shiny and silky appearance were composed of gelatinous fibres (TW). A

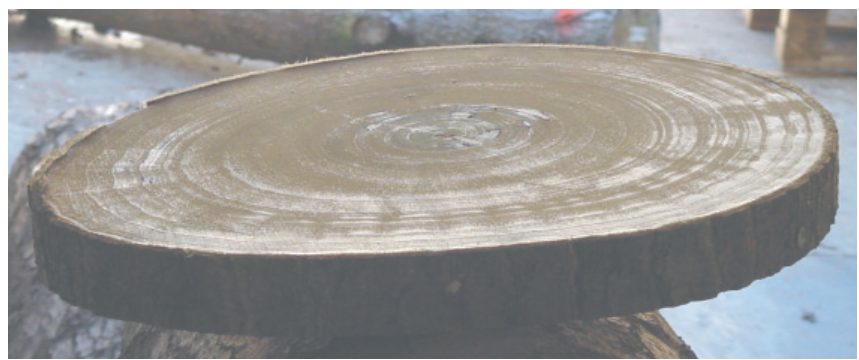

Figure 2. Tension wood areas from the cultivars MC viewed under a low angle natural light.

microscopic validation by 80 thin sections $(15 \mu \mathrm{m}$ thick $)$ double stained with safranine and astra blue, verified the relevancy of results [3]. Figure 1B shows the TW distribution inside the stem and a clear longitudinal continuity along several discs.

The height of the analysed stems was between $15-17.5 \mathrm{~m}$, including a "trunk zone" which corresponds to the pruned length, up to $8 \mathrm{~m}$ and the "crown zone" to the non-pruned length, and the total number of discs and growth rings were 298 and 3801, respectively. Table II sums up for each tree the number of growth units, discs, growth rings, stem height and the position of the first green branch and dead branch (pruned height). For each growth unit we sampled several discs, to calculate the proportion of TW per growth unit and per growth ring. The results presented in this paper were generally confirmed by statistical analysis (SAS ${ }^{\circledR}$ GLM procedure) and the comparisons of means were based on the Student-Newman-Keuls (SNK) test. Nevertheless, the authors draw the attention of the reader to the risk of generalisation of statistical results based on such a small number of trees.

\section{RESULTS}

\subsection{Inter-clonal variability of tension wood}

Figure 3 shows in a bar chart the mean values per cultivar and for each of the nine trees analysed. The TW percentage varied considerably between the different cultivars. Luisa Avanzo

Table II. Number of growth units, discs, growth rings and height analyzed. The height of the green branch (H1bg) and the height of the first dead branch (H1bd) are also shown.

\begin{tabular}{|c|c|c|c|c|c|c|}
\hline Clone & $\mathrm{Nb}$ growth units & $\mathrm{Nb}$ discs & $\mathrm{Nb}$ growth rings & Height (m) & H1bg (m) & H1bd (m) \\
\hline I1 & 8 & 34 & 416 & 16.8 & 10.7 & 8 \\
\hline I2 & 8 & 32 & 425 & 15.5 & 11.4 & 9.1 \\
\hline I3 & 8 & 34 & 396 & 16.6 & 11.3 & 8.4 \\
\hline LA1 & 6 & 31 & 420 & 15.4 & 12.2 & 7.6 \\
\hline LA2 & 7 & 32 & 425 & 15.6 & 12.4 & 10.3 \\
\hline LA3 & 7 & 34 & 447 & 16.7 & 8.2 & 7.5 \\
\hline $\mathrm{MC} 1$ & 7 & 36 & 436 & 17.5 & 14.7 & 9 \\
\hline MC2 & 7 & 33 & 426 & 16.7 & 13.6 & 10.1 \\
\hline MC3 & 8 & 33 & 410 & 17.6 & 14.9 & 8.9 \\
\hline
\end{tabular}




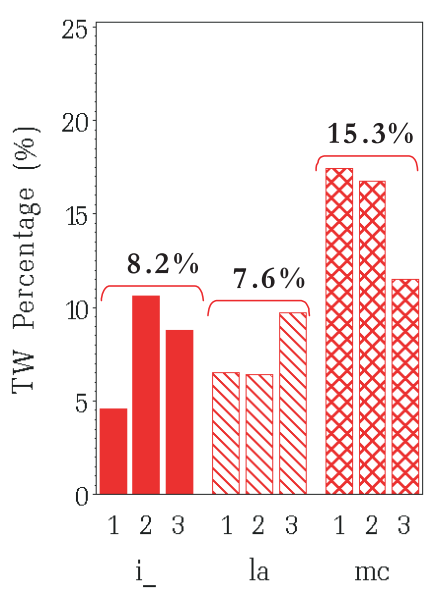

A

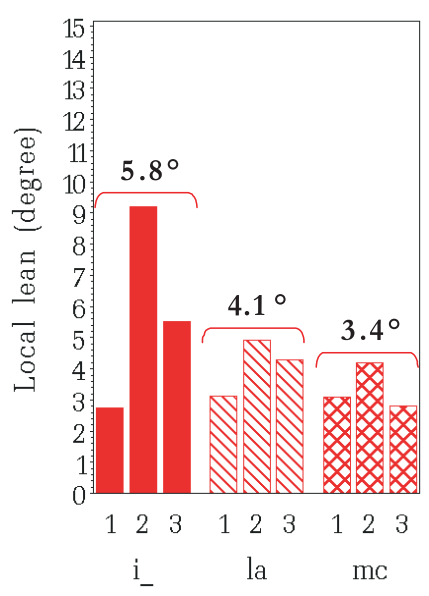

B

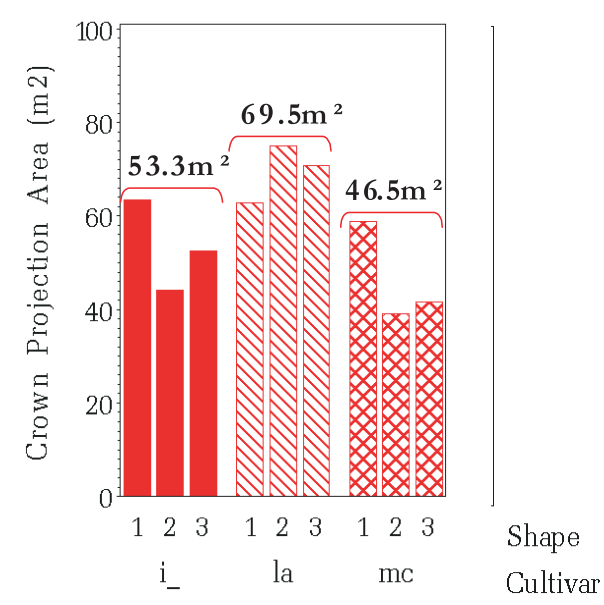

C

Figure 3. Mean values per tree (bar height) and mean values per cultivar (number): $(\mathbf{A})$ Tension wood percentage $(\%) ;(\mathbf{B})$ Local lean $\left({ }^{\circ}\right)$ and (C) Crown projection area $\left(\mathrm{m}^{2}\right)$. The shape-index correspond to: (1) straight tree; (2) leaning tree and (3) flexuous tree. The cultivars are abbreviated by: $i_{-}$for I214; la for Luisa Avanzo; mc for I-MC.

and $\mathrm{I} 214$ presented a small proportion of TW, $7.6 \%$ and $8.2 \%$ respectively, while it was much higher in I-MC cultivars $(15.3 \%)$. These substantial differences between cultivars corroborate the observations carried out by other authors: Sacré [31] observed in some 3-year-old stems, very strong differences between I214 (16\%) and Robusta (40\%); Leclercq [24] classified ten other cultivars between 7 and 16 years of age, in three levels: $8 \%, 15 \%$ and $40 \%$.

The TW percentage obtained in our study for the I214 cultivars was weaker than that reported by Sacré [31]. This difference can be explained by the age difference between the two samples ( 3 and 16 years respectively). A comparison at equal age ( 3 years) showed that I214 cultivars of our sampling had an average proportion of TW equal to that observed by Sacré (16.4\% versus $16 \%$ in Sacré sampling). Concerning Luisa Avanzo and I-MC cultivars, there is no data in the literature on TW percentage. Considering our data, the differences between the average TW percentages were statistically significant $(p$ value $>0.0001$ ) for the clone I-MC. LA and I214 cannot be distinguished except for some of the first growth units.

I-MC cultivars had the narrowest crown area $\left(46.5 \mathrm{~m}^{2}\right)$ and the highest TW content. By contrast, Luiza Avanzo exhibited a low TW percentage and large crown areas $\left(69.5 \mathrm{~m}^{2}\right)$. The $\mathrm{I} 214$ cultivar was between these two extremes. Because of the low number of trees involved in our study, a negative correlation between crown areas and TW percentage could not be established, nevertheless these results are in agreement with the observations made on the beech by Ferrand [17] and the European Project "Stress in Beech" [16]. However, they are in disagreement with Berlyn [7], who found a weak but positive relationship between crown projection area and tension wood percentage in 84 Populus deltoides (Correlation Coefficient, $r=0.19)$.

The mean local lean (Fig. 3B) shows that the straighter cultivar was I-MC $\left(3.4^{\circ}\right)$, followed by Luisa Avanzo $\left(4.1^{\circ}\right)$ and I214 $\left(5.8^{\circ}\right)$. This classification does not have a general significance, considering that the strategy used for selecting the trees was based on shape index. Compared to TW percentage (Fig. 3A), the cultivars with the best tree morphology (I-MC) presented the highest percentage of TW (15.3\%). This result underlines the importance of knowing the wood quality for selection. In this case, morphological factors are not the best criterion to take into account in poplar plantations in order to produce wood with lower values of TW. Similar results have often been observed by other authors in the genus Populus [19, 22, 23] Isebrands and Bensend [19] put forth the assumption that the cambium of this species would be particularly sensitive to the stimuli involved in the formation of TW.

\subsection{Intra-tree variability of tension wood}

\subsubsection{Longitudinal distribution}

Figure 4 presents the longitudinal distribution of TW. One tree per cultivar and per shape-index are illustrated: straight I214, leaning Luisa Avanzo and flexuous I-MC. In addition to TW distribution, a line was added to indicate the height position for each branch measured in the field. In this way, we can see the different behaviour of TW distribution between "trunk zone" (pruned stem) and "crown zone". In the "crown zone", the occurrence of TW was quite irregular. In the "trunk zone", TW percentage was rather continuous and regular except in the bottom of the stem. In seven of the nine trees studied, the percentage of TW at the bottom of the stem (below $50 \mathrm{~cm}$ ) was higher than in the discs located just above. The same characteristic was observed by Washusen et al. [35] in 1011 year-old Eucalyptus globulus Labill. and by Jourez [21] and Delavault et al. [15] in young stems of poplar and Eperua falcata respectively. In six out of nine trees, if the first $50 \mathrm{~cm}$ were not considered, the proportion of TW tended to increase slightly with the height. In the litterature both situations have been reported, TW increasing with the height in: poplar [19, 23, 


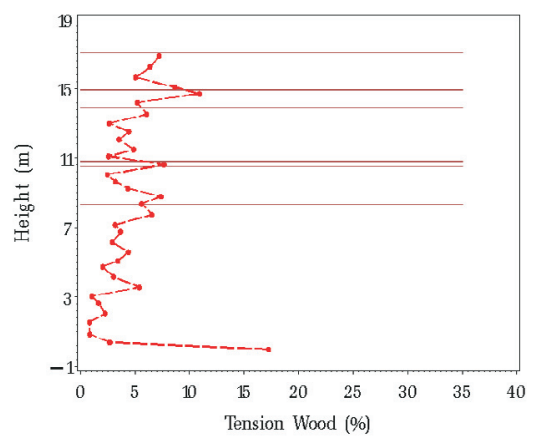

A

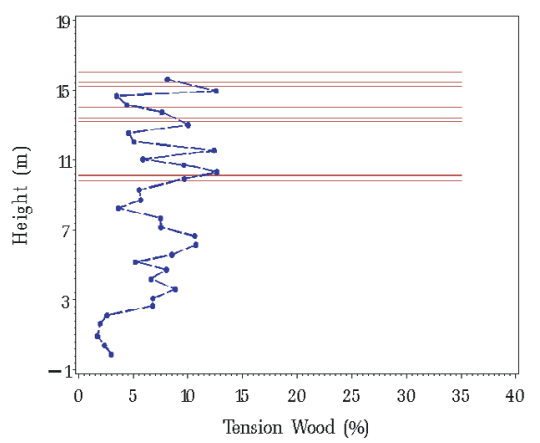

B

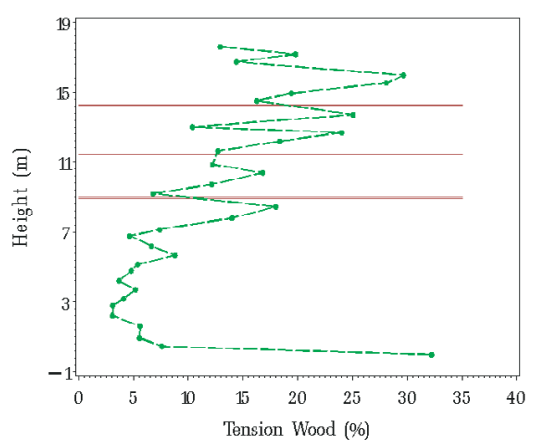

C

Figure 4. Height distribution of TW percentage for three trees: (A) straight I214; (B) leaning Luisa Avanzo and (C) flexuous I-MC. Each symbol corresponds to a disc and the horizontal lines show the position of branches measured in standing trees.

26, 32] or beech [13] and TW decreasing with height [21, 30, 34]. The different results from the literature would be explained by the position of the samples analysed by the authors. In fact, according to the position of the discs sampled, closer to the butt portion of the tree or to the top, the trend could be reversed.

\subsubsection{Radial distribution}

Figure 5 illustrates the distribution of TW percentage observed in each growth ring according to their radial position. The data were divided per cultivar (I214, Luisa Avanzo and I-MC) and per stem zone according to the longitudinal position of the discs ("trunk zone" or "crown zone"). The plots coming from the "trunk zone" and from any cultivar showed a clear bimodal distribution (two peaks). On the other hand, the discs sampled in the "crown zone" did not follow a bimodal distribution. In fact, this bimodality indicates that the phenomenon of TW appearance is not homogenous during the tree growth and the observations result from two "overlapping" distributions. One is composed by the first growth rings that are close to the pith and the other one by the growth rings formed the last years of the tree life, i.e. close to the bark.

In the first distribution, the high TW percentage decreases strongly with the tree growth. This reduction in TW occurrence could be linked to the increase of stiffness due to larger diameter. This stage was called "establishment growth period". The proportion of TW reaches a minimum, which is, for the three cultivars, situated in a similar radius between 90 and $100 \mathrm{~mm}$. Field observations showed that until this diameter (between 8 and 10 years) the trees were in open growth with no competition for light. The second peak corresponds to the moment when crowns begin to touch and interact, i.e. to the canopy closure. If it is considered that following the canopy closure the phototropic response of the trees forces them to increase their surface exposed to the light, and thus to change the position of the branches and even of the stem, this process must be inevitably accompanied by a production of TW. This second growth stage was called "competition growth period". Coming back to the "crown zone", a radial decrease of TW percentage is visible close to the pith especially for I214 and LA. The reasons of the decrease had the same origin than in the "trunk zone". The min- imum value seems to be closest to the pith than in the trunk zone as it could be expected according to the hypothesis of the coincidence with canopy closure. The second peaks are less visible. Several reasons could be put forward: the local distribution of tension wood could be disturbed by branches at this level, and there was not enough radial increment recording through TW the change in competition.

This kind of radial reaction wood distribution has been reported in several poplars and coniferous, and called "waves of reaction wood" $[8,10,15,25,27,33]$. The authors consider that part of the first wave corresponds to the reorientation of the stem and the second wave, elaborated in mature age, to the stabilisation of the tree. In addition, these waves are explained also by a thinning effect or by the death of the apical meristem. However, the effet of the canopy closure in the production of TW has never been observed before.

\subsubsection{D Tension Wood map}

Figure 6 shows in a 2D map the radial (growth rings) and longitudinal (growth units) distribution of TW for the nine sampled trees. The longitudinal data was limited in order to homogenize the nine pictures, we mapped for all trees up to the sixth growth unit. The average of TW percentage was represented in a grey scale where each step was $2.5 \%$.

We can notice the longitudinal increase in TW between the "trunk zone" (up to the fourth growth unit for Luisa Avanzo and I-MC and fifth growth unit for I214) and the "crown zone", especially for the growth rings close to the pith. An ANOVA was carried on this set of data for testing the effects of cultivar, shape, and age from the pith for each growth unit. The statistical analysis showed that the shape effect on TW percentage was very significant for the first growth units $(\mathrm{GU} \leq 4, p$-value $<$ $0.0001)$ and the degree of significance decreased towards the crown ( $p$-value $=0.0209$ for GU5, $p$-value $=0.5591$ for GU6). A variation of TW distribution was also observed in the radial direction. We found that the bimodal distribution of TW was clearer in the first growth units than in the crown. Regarding the basal effect observed in Figure 4, it is not visible in Figure 6 because it is hidden by the average of several discs per growth unit. 

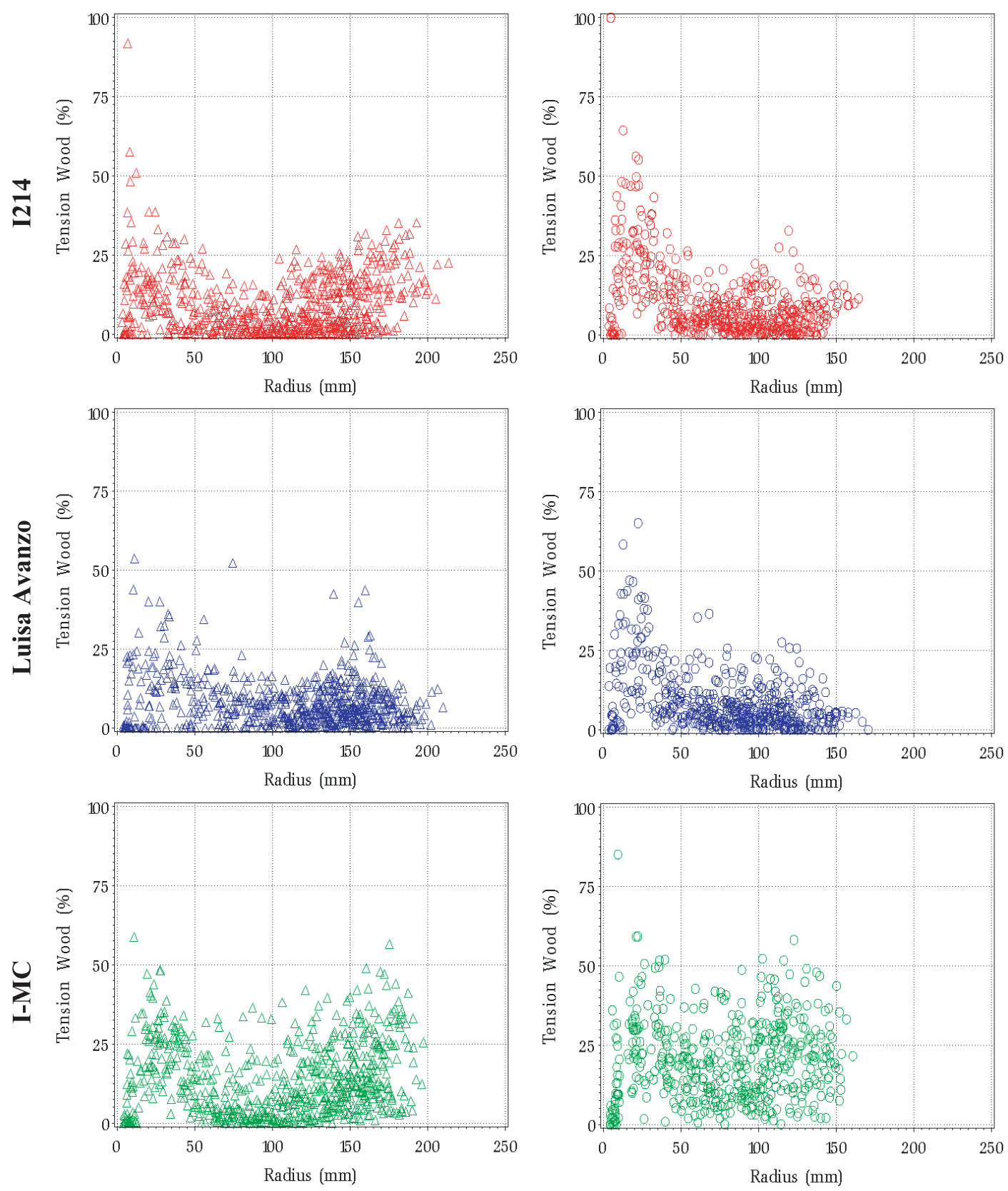

Trunk zone

\section{Crown zone}

Figure 5. Radial distribution of tension wood per cultivar and stem zone. Each symbol represents the tension wood percentage observed in a growth ring. The three shape-indices per cultivar are mapped in the same data set and divided according to their longitudinal position ("trunk zone" or "crown zone").

\section{CONCLUSIONS}

The main characteristics of I-MC cultivar were: strong apical dominance, fast growth and very good morphological character. However, it had a proportion of TW (15.3\%) higher than the other clones which can result in many technological problems during the industrial wood processing [6]. Luisa Avanzo and $\mathrm{I} 214$ produced only $7.6 \%$ and $8.2 \%$ of TW respectively, but the main disadvantage of Luisa Avanzo is the huge quantity of wetwood (up to $40 \%$, [5]) and the flexuosity for I 214 .
Thus the choice of the cultivar to be planted cannot be only based on morphological characters and fast growth, since wood properties, like TW, associated to each cultivar are essential. We have seen that the crown projection area could be a good inter-cultivar indicator of TW occurrence. Cultivars with narrow crowns correspond to the trees with highest values of TW and the widest crowns correspond to cultivars with the lowest percentages of TW.

The spatial distribution of TW showed that it was located predominantly below $30-50 \mathrm{~cm}$. If this basal part is eliminated, 


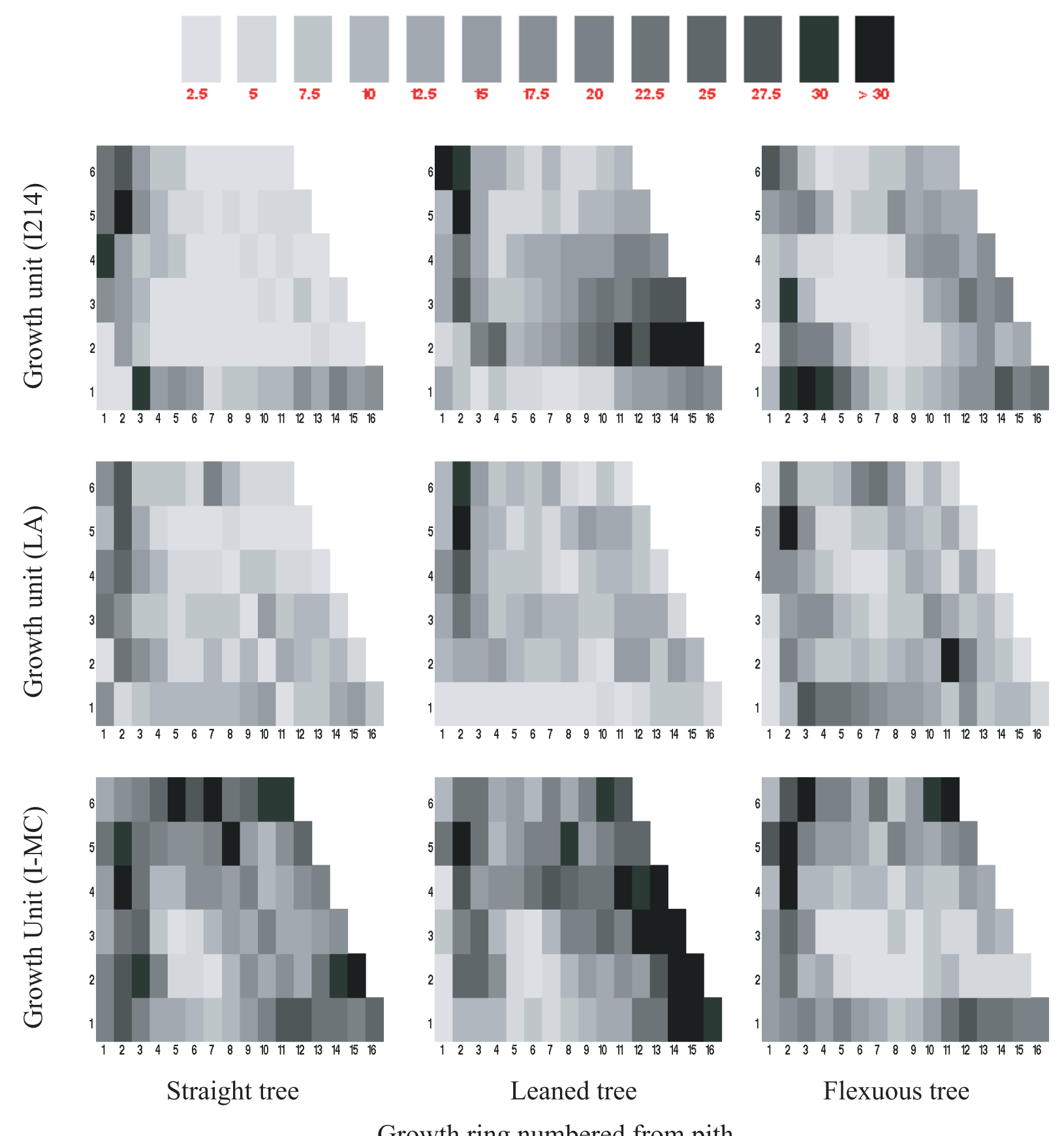

Growth ring numbered from pith

Figure 6. Tension wood distribution for the nine poplars up to the sixth growth unit (UC) and for each growth ring. The grey level legend shows the percentage of tension wood inside one growth ring and one growth unit.

the production of TW increased slightly towards tree height. This longitudinal distribution suggests that TW content estimated through sampled cores taken below $50 \mathrm{~cm}$ in the stem lead to overestimate the real proportion of TW in the whole stem.

In the pruned stem (up to $8 \mathrm{~m}$ ), the radial distribution of the percentage of TW (calculated per growth ring) presented a clear bimodal structure. During the first peak, "establishment growth period", the trees were in open growth and the high proportion of TW was probably due to a high sensitivity to environmental stimuli as wind or non uniform crown development added to a slight stiffness of the stem. During the first stages of the tree growth, TW occurrence decreased strongly until the canopy closure, which appeared when the trees were between 18 and $20 \mathrm{~cm}$ in diameter. After this event, the phototropic response of the trees was inevitably accompanied by a major production of TW, a stage called "competition growth period". 
The effect of canopy closure on the distribution of TW shows the relevance for the selection process of the plantation density, which must be in accordance with the growth rate and phototropic response of the different cultivars available.

\section{REFERENCES}

[1] Arganbright D.G., Bensend D.T., Relationship of gelatinous fiber development to tree lean in soft maple, Wood Sci. 1 (1968) 37-40.

[2] Badia M., Modélisation de la distribution du bois de tension dans une grume de peuplier à partir de l'empilement tridimensionnel des cernes. Cas des cultivars I214, Luisa Avanzo et I-MC, Thèse de doctorat en Sciences du Bois, ENGREF, 2003, p. 215.

[3] Badia M., Mothe F., Constant T., Nepveu G., Assessment of tension wood detection based on shiny appearance on three poplar cultivars, Ann. For. Sci. 62 (2005) 43-49.

[4] Bamber R.K., A general theory for the origin of growth stresses in reaction wood: how trees stay upright, IAWA J. 22 (2001) 205-212.

[5] Baonza V., Gutiérrez A., Variación de algunas características dendrométricas y físicas, según su posición en el tronco. Caso de Populus $\times$ euramericana (Dode) Guinier cv. "LUISA AVANZO", in: Rivas M. (Ed.), II Congreso Forestal Español, Pamplona, 1997, pp. 69-74.

[6] Baonza V., Gutiérrez A., Rendimiento y calidades de chapa en los clones de chopo a diferentes alturas del fuste, Investig. Agrar. Sist. Recur. For. 11 (2002) 311-323.

[7] Berlyn G.P., Factors affecting the incidence of reaction tissue in Populus deltoides Bartr, IOWA State J. Sci. 35 (1961) 367-424.

[8] Boury S., Estimation quantitative de la répartition du bois de tension chez le peuplier (Populus $\times$ euramericana $\mathrm{cv}$. I214) à partir de l'hétérogénéité circonférencielle de la densité du bois, Internal document Équipe Qualité des Bois du LERFoB, INRA-Nancy, 1993, p. 34.

[9] Cano-Capri J., Burkart L.F., Distribution of gelatinous fibers as related to lean in southern red oak (Quercus falcata Michx.), Wood Sci. 7 (1974) 135-136.

[10] Chanson B., Hétérogénéités angulaires des déformations de maturation : Interprétation basée sur le concept de Plan d'Organisation des Arbres, in: Thibaut B. (Ed.), IVe Séminaire Architecture, Structure, Mécanique de l'Arbre, LMGC, Université de Montpellier II, Montpellier, 1992, pp. 121-131.

[11] Chantre G., Le bois de tension dans le genre Populus : effet clonal à un stade juvénile ; conséquences d'une sélection précoce sur quelques paramètres technologiques, in: Thibaut B. (Ed.), Ve Séminaire Architecture, Structure, Mécanique de l'Arbre, LMGC, Université de Montpellier II, Montpellier, 1993, pp. 139-162.

[12] Clair B., Thibaut B., Shrinkage of the gelatinous layer of poplar and beech tension wood, IAWA J. 22 (2001) 121-131.

[13] Clarke H., The distribution, structure, and properties of tension wood in beech (Fagus sylvatica L.), J. For. XI (1937) 85-93.

[14] Constant T., Mothe F., Badia M., Saint-André L., How to relate the standing tree shape to internal wood characteristics: Proposal of an experimental method applied to poplar trees, Ann. For. Sci. 60 (2003) 371-378.

[15] Delavault O., Chanson B., Fournier M., Interprétation de la répartition longitudinale du bois de tension dans de jeunes tiges d'Eperua falcata Aubl. (Caesalpiniaceae), in: Thibaut B. (Ed.), IV e Séminaire Architecture, Structure, Mécanique de l'Arbre, LMGC, Université de Montpellier II, Montpellier, 1992, pp. 66-83.

[16] EU-FAIR Project. Occurrence and Relevance of Growth Stresses in Beech (Fagus sylvatica L.) in Central Europe, Institut für Fostbenutzung und Forstliche Arbeitswissenschaft Albert-LudwigsUniversität Freiburg (Germany), 2002, p. 323.
[17] Ferrand J.C., Étude des contraintes de croissance. Deuxième partie: variabilité en forêt des contraintes de croissance du hêtre (Fagus sylvatica L.), Ann. Sci. For. 39 (1982) 187-217.

[18] Grzeskowiak V., Sassus F., Fournier M., Coloration macroscopique, retraits longitudinaux de maturation et de séchage du bois de tension du peuplier (Populus $\times$ euramericana cv. I214), Ann. Sci. For. 53 (1996) 1083-1097.

[19] Isebrands J.G., Bensend D.W., Incidence and structure of gelatinous fibers within rapid-growing Eastern Cottonwood, Wood Fiber 4 (1972) 61-71.

[20] Jourez B., Technique de détection du bois de tension du peuplier sur échantillon massif, in: Thibaut B. (Ed.), Ve Séminaire Architecture, Structure, Mécanique de l'Arbre, LMGC, Université de Montpellier II, Montpellier, 1993, pp. 121-137.

[21] Jourez B., Distribution and quantification of tension wood in poplar shoots, in: IPC (Ed.), 20th International Poplar Commission, Budapest, Hungary, 1996, pp. 1-7.

[22] Kaeiser M., Boyce S.G., The relationship of gelatinous fibers to wood structure in eastern cottonwood (Populus deltoides), Am. J. Bot. 52 (1965) 711-715.

[23] Kroll R.E., Ritter D.C., Gertjejansen R.O., Au K.C., Anatomical and physical properties of balsam poplar (Populus balsamifera L.) in Minnesota, Wood Fiber Sci. 24 (1992) 13-24.

[24] Leclercq A., La qualité du bois de quelques nouveaux cultivars belges de peuplier, Document interne Station de Technologie Forestière de Gembloux, 1989, p. 19.

[25] Loup C., Relations entre Architecture, Mécanique et Anatomie de l'arbre: Cas d'un pin maritime (Pinus pinaster Soland), in: Thibaut B. (Ed.), II ${ }^{\mathrm{e}}$ Séminaire Architecture, Structure, Mécanique de l'Arbre, LMGC, Université de Montpellier II, pp. 55-68.

[26] Müller-Stoll W.R., Zenker R., Abbau der Wandsubstanz von Zugholzfasern der Pappel durch holzzerstorende Pilze und die Besonderheiten der G-Schicht, Drevarsky Vyskum 110 (1986) 1-12.

[27] Radi M., Castéra P., Qualification de la forme de deux pins maritimes en liaison avec la structure de leur bois, Ann. Sci. For. 49 (1992) 185-200.

[28] Ritter D.C., Kroll R.E., Gertjejansen R.O., Zones of gelatinous fibers in Populus balsamifera, Wood Fiber Sci. 25 (1993) 198-208.

[29] Sacré E., Le bois de tension des peupliers, Bull. Inst. Agron. Stat. Rech. Gembloux XXVII (1959) 435-444.

[30] Sacré E., Étude du bois des peupliers euraméricains d'origine belge et étrangère, Revue Agricole 4 (1964) 531-534.

[31] Sacré E., Proportion de faux cœur et de bois de tension dans les peupliers «Robusta » élagués et non élagués, Document Station de Technologie Forestière, Gembloux, 1974, p. 6.

[32] Sacré E., Caractéristiques anatomiques et physiques du bois des peupliers "I. 214", "robusta" and "gelrica" aux stades précoce et adulte, Bull. Soc. Roy. For. Belg. 84 (1977) 321-338.

[33] Thomas R., Analyse des formes de troncs par photogrammétrie pour caractériser la qualité des bois. Application au pin sylvestre de Lozère, Thèse de doctorat en Sciences du Bois, ENGREF, 2000, p. 204.

[34] Washusen R., Tension wood occurrence in Eucalyptus globulus Labill. II. The spatial distribution of tension wood and its association with stem form, Aust. For. 65 (2002) 127-134.

[35] Washusen R., Ilic J., Waugh G., The relationship between longitudinal growth strain, tree form and tension wood at the stem periphery of ten-to eleven-year-old Eucalyptus globulus Labill., Holzforschung 57 (2002) 308-316.

[36] Wilson B.F., Response to stem bending in forest shrubs: stem or shoot reorientation and shoot release, Can. J. Bot. 75 (1997) 16431648.

[37] Wilson B.F., Gartner B.L., Lean in red alder (Alnus rubra): growth stress, tension wood, and righting response, Can. J. For. Res. 26 (1996) 1951-1956. 